\title{
The experience of personal growth in different career stages: An exploratory study
}

\author{
Sabine Hommelhoff • Carina Schröder · Cornelia Niessen
}

\begin{abstract}
We examine whether the experience of personal growth at work changes over the course of one's career. Interviews with 29 childcare providers revealed that personal growth was felt after mastering challenges. The nature and content of these challenges seemed to vary according to career phase. Early-career individuals considered their daily work challenging. Professionals in the middle of their careers focused more on social conflicts and their resolutions, while professionals at the end of their careers were more likely to see unique, non-routine tasks as challenges. This study suggests that personal growth cannot be fully understood independently of career phase. Implications are discussed.
\end{abstract}

Keywords Personal growth $\cdot$ Career $\cdot$ Challenge

The Authors Sabine Hommelhoff and Carina Schröder contributed equally to the manuscript.

Dr. S. Hommelhoff $(\bowtie) \cdot$ C. Schröder, M.Sc. · Prof. Dr. C. Niessen

Institut für Psychologie, Friedrich-Alexander Universität Erlangen-Nürnberg (FAU),

Nägelsbachstr. 49c, 91052 Erlangen, Germany

E-Mail: sabine.hommelhoff@fau.de

C. Schröder, M.Sc.

E-Mail: carina.c.schroeder@fau.de

Prof. Dr. C. Niessen

E-Mail: cornelia.niessen@fau.de 


\section{Persönliches Wachstum in unterschiedlichen Karrierephasen: Eine explorative Studie}

Zusammenfassung Verändert sich das Erleben von persönlichem Wachstum bei der Arbeit im Laufe der Karriere? Interviews mit 29 Erziehern/innen zeigten, dass persönliches Wachstum nach der Bewältigung von Herausforderungen erlebt wurde. Art und Inhalt dieser Herausforderungen schienen aber je nach Karrierephase zu variieren. Personen am Anfang ihrer Karriere fanden ihre tägliche Arbeit herausfordernd. In der Karrieremitte wurde oft von sozialen Konflikten und deren Lösung berichtet, während am Karriereende eher besondere, nicht routinemäßige Aufgaben als Herausforderungen galten. Dies zeigt, dass man persönliches Wachstum nicht unabhängig vom Karrierestadium verstehen kann. Implikationen werden diskutiert.

Schlüsselwörter Persönliches Wachstum · Karriere $\cdot$ Herausforderung

\section{Introduction}

Work is a double-edged sword: It can be a source of hardship and stress, but also a source of growth and well-being. Numerous studies have shown that personal growth at work is an important issue for workers in that it is related to increased health and well-being (e.g., Shirom et al. 2008), job performance (e.g., Carmeli et al. 2009), and innovation (e.g., Carmeli and Spreitzer 2009). Thus, it is not only important for organizations to promote their employees' personal growth, but also for employees to seek and create opportunities for development at work.

Although there are already several conceptualizations of personal growth at work, such as thriving (e.g., Spreitzer et al. 2012, 2005) or flourishing at work (e.g., Dutton et al. 2011), no studies focus on possible changes in how employees construe and experience personal growth across the career span. This comes as a surprise given demographic changes, that is, the aging of society in Germany and many other countries (Hertel and Zacher 2015). Many of today's employees will retire a few years later than was previously common. Therefore, the question of how to develop one's potential at work into the late stages of one's career is of strong relevance. At the same time, there is increasing competition among organizations to attract younger employees (McDonnell 2011); hence, it is just as relevant to understand how people can develop and grow at work at the beginning or middle of their careers. Consequently, this research aims to explore personal growth from a career perspective. We ask whether and how workers differ in their experience of personal growth at work over the course of their professional careers. Over the course of a professional career, workers face different developmental tasks, social expectations, and changing priorities in terms of work and private roles (Super 1980); hence, it is likely that workers experience growth resulting from various events and actions over the course of their careers. To address this question, we conducted grounded theorybased interviews (Glaser and Strauss 1967) with childcare providers. Overall, this exploratory study aims to take a first step towards integrating career and personal 
growth research. It further strives to develop recommendations for practitioners on how to support employees' personal growth at different career stages.

\section{Theoretical Considerations}

\subsection{Personal growth (at work)}

What is personal growth? The idea of personal growth has its roots in the concept of hedonic-eudaimonic well-being, introduced by Aristotle in the 4th century B. C. E. (Aristotle 2001). Hedonic well-being refers to pleasant experiences and positive affect in the here and now, while eudaimonic well-being involves a focus on development, meaning, and fulfilment, both in the present and in the future (Huta 2015). Conceptualizations of personal growth often emphasize the eudaimonic aspect of well-being. For example, Ryff (1995) developed a conceptualization of well-being that includes personal growth, with the idea in mind that, for Aristotle, eudaimonia was the highest of all goods achievable by human action (Ryff and Singer 2008). She describes personal growth without mentioning hedonic terms like enjoyment, pleasure, painlessness, satisfaction, or comfort. Instead, she emphasizes that the experience of personal growth involves feelings of continuous development, a sense of the self as expanding and of having realized one's potential, new experiences, and heightened self-knowledge (Ryff 1995).

The two most prominent conceptualizations of personal growth in the work context, thriving and flourishing, include both eudaimonic and hedonic components. Thriving (Spreitzer et al. 2005) refers to a psychological state of learning and vitality. Learning refers to the sense that one is acquiring new skills and knowledge (Elliott and Dweck 1988), while vitality or vigor refers to the subjective experience of liveliness and energy (Peterson and Seligman 2004; Ryan and Frederick 1997; Shirom 2003). Thus, thriving involves both a cognitive-eudaimonic and an affective-hedonic dimension and predicts both performance and well-being at work (see Spreitzer et al. 2005; for a short overview). It has been shown that the experience of thriving depends on work characteristics (Prem et al. 2017) and individuals' personal and social resources (e.g., Niessen et al. 2017, 2012; Paterson et al. 2014; for a meta-analytic overview, see Kleine et al. 2019). Flourishing is a broader construct than thriving and refers to a high level of mental health, which includes both emotional-hedonic well-being (e.g., feeling satisfied and interested in life) and positive functioning (e.g., feeling accepted and liked by others, feeling that one is making important contributions to society; Diener et al. 2009; Keyes 2002). In the work context, flourishing involves a sense of motivation, engagement, and learning for both individuals and collectives within organizations (Dutton et al. 2011).

Other conceptualizations of personal growth at work relate only to the eudaimonic aspect of well-being, thus emphasizing that growth can happen even when work is not full of fun and joy. For example, individuals with a high growth need strength want to learn and develop and focus strongly on opportunities and internal rewards at work (Hackman and Oldham 1976, 1980). Moreover, resilience at work is defined as a positive developmental progression after experiences of adversity at work (Caza 
and Milton 2012). It refers to the ability to cope with stressors and threatening circumstances and to use them as an impetus for further development and professional growth (Caza and Milton 2012; Lamb and Cogan 2016). Similarly, posttraumatic growth has been considered a form of personal growth that can be the consequence of coping with traumatic experiences and crises (Tedeschi and Calhoun 2004). In the work context, posttraumatic growth has been studied in occupations that involve dealing with crisis situations on a daily basis (e.g., fire and rescue service; Paton 2014).

In our study, we ask interviewees how they experience and construe personal growth. That is, we do not employ a specific conceptualization of growth, but focus on the participants' individual understandings of growth. Therefore, it was up to the interviewees whether they wished to emphasize the hedonic and/or eudaimonic aspect of personal growth.

\subsection{A career perspective}

Today's work environment has been characterized as volatile, uncertain, complex, and ambivalent (VUCA; Bennett and Lemoine 2014). Long-term careers in organizations are not as common as they used to be (Cappelli 1999); many individuals change jobs at least once in their lifetime-as a personal choice or due to organizational changes. This has led to the development of new approaches in career research (for an overview, see Nagy et al. 2019). For example, the term protean career foregrounds the agency of the individual, who makes career decisions based on personal values and defines career success in subjective terms (Hall 2004). However, even in dynamic work environments, (developmental) tasks and demands still vary for employees depending on their work experience and age. Therefore, in order to explore how workers experience personal growth in different phases of their careers, we referred to Super's traditional career stage model (Super 1957, 1980), still one of the most influential theories in career research (Nagy et al. 2019).

According to Super (1980, p. 282), a career is the "combination and sequence of roles played by a person during the course of a lifetime." He identifies four stages over a professional career: exploration, establishment, maintenance, and decline (Super 1957, 1980). Employees in the exploration stage are typically in contact with the work context for the first time. They will try out different roles and activities to find out what is important to them in their professional lives and generate interests and skills. In the establishment stage, employees want to pursue a successful career within their organization. The maintenance stage describes employees who are productive at work but simultaneously dealing with developmental tasks in their private lives. In the decline stage, employees also devote time and effort to planning their lives after leaving work.

Although this traditional conceptualization of a career as a defined sequence might not correspond to some of today's dynamic and flexible careers (Nagy et al. 2019), we have opted for this career model because we want to focus on developments and tasks over the career span and not on individual career design. Thus, we consider Super's stages a heuristic to help interviewees describe the current phase and developments in their careers. That being said, we wish to note that our research 
proceeds from the assumption that personal growth is both possible and desirable at all stages of professional careers. The term "decline" (Super 1980) masks the fact that development and growth are also possible in later stages of professional careers (Taneva et al. 2016).

\section{Method}

\subsection{Design and participants}

To explore personal growth from a career perspective, we used the grounded theory approach (Glaser and Strauss 1967), a qualitative methodology for phenomena that are not yet well researched. A core principle of this approach is that data collection and analysis are closely interrelated and inform one another. That is, after each interview, we analyzed the data and discussed whether to adjust the interview questions (Corbin and Strauss 2015; Glaser and Strauss 1967). A further principle of this methodology is to stop data collection and analysis when no new concepts or information can be extracted from the data. We reached this so-called theoretical saturation after 29 interviews.

Thus, our final sample consisted of 29 childcare providers $(89.7 \%$ female; $M=38.72$ years old, $S D=11.97$ years, range $21-62$ years old) from different institutions in Germany (e.g., pre-kindergarten, nursery schools). Their average amount of job experience was 14.09 years $(S D=12.96$ years, range $0.10-45$ years $)$, and their average organizational tenure was 6.16 years $(S D=6.82$ years, range $0.10-22$ years). On average, they worked $35.12 \mathrm{~h}$ per week $(S D=5.28 \mathrm{~h}$, range $20-40 \mathrm{~h})$. Approximately half of participants $(48.3 \%)$ had children of their own.

We selected this professional group for three reasons:

1. Childcare providers have a broad social network and many social interactions on a daily basis (e.g., with children, parents, colleagues, and supervisors) - that is, they are embedded in a rich social context, which facilitates personal growth (Spreitzer et al. 2005).

2. Childcare providers support small children in their development and therefore often deal with the topics of development and growth in general.

3. Finally, we focused on a single professional group because we wanted to analyze differences over the career span and not differences across professions.

\subsection{Materials, procedure, and analysis}

Semi-structured interviews were conducted between March and September 2017 (Mey and Mruck 2010). In these interviews, the respondents were asked to describe how they construe and perceive personal growth at work. In particular, they were asked to describe specific work experiences or events after which they experienced a sense of personal growth or, in contrast, stagnation. Sentence completion tasks were also employed. To assign the interviewees to the different career phases (Super 1980), we presented a brief description of each career stage in the form of several 
statements (e.g., "My professional future is full of opportunities and I have the feeling that I can develop in many directions" for the exploration phase; "I am pursuing my professional career and want to be successful in it" for the establishment phase; "I have to be able to manage work and private life in such a way that I do justice to both areas" for the maintenance phase; "Sometimes I think more about my future life outside work (e.g., my retirement), even if it still takes a while" for the decline phase). Seven respondents assigned themselves to Career Stage 1 (24.1\%, exploration), seven to Career Stage 2 (24.1\%, establishment), nine to Career Stage 3 (31.0\%, maintenance), and six to Career Stage 4 (20.8\%, decline).

The interviews were transcribed verbatim and coded with the help of the MAXQDA 12 software. In line with the core principles of grounded theory (Glaser and Strauss 1967), the second author coded all themes from the first interview and used them as the basis for coding the next interview. In a stepwise and emergent process, the second author formed abstract codes and categories by grouping similar topics together. After the second author had completed this primary coding process, interrater agreement was determined. That is, an independent coder also coded $10 \%$ of the material (i.e., 199 interview passages out of a total of 1990 passages). Agreement between raters was $94 \%$. Cohen's $\kappa$ was 0.92 , suggesting high agreement (Bakeman and Gottman 1986).

\section{Results}

The interviewed childcare providers offered a wide range of ideas and definitions of personal growth at work. Based on their notions, we suggest defining personal growth at work as a continuous process or discrete event that involves the experience of positive affect (i.e., a hedonic aspect) as well as personal, cognitive, and social development (i.e., a eudaimonic aspect). People grow in response to challenging events as well as due to their active search for or initiation of challenging demands.

Some differences and accentuations in the interviewees' responses emerged depending on career stage (also see Fig. 1 for a summary and overview). Overall, the interviewees differed depending on career stage in conceptualizing growth as continuous or discontinuous, in how they defined a challenge at work, and in focusing on developments at either the personal, cognitive, or social level.

\subsection{Continuous growth and discrete (challenging) events}

Some of the interviewees described their experience of personal growth at work as a continuous process, meaning that they felt they grew regularly and constantly while interacting with their environment. In contrast, some childcare providers experienced personal growth as a result of discrete events. For example, some childcare providers reported that after a period without growth, they started experiencing personal growth again due to a challenging event. This sense of growth then lasted for a while, until they once again entered a period of non-growth: 


\section{Personal growth at work}

Experience of (short-term) positive affect and (long-term) personal, cognitive, and social development after mastering challenging demands

\begin{tabular}{|c|c|c|c|}
\hline Career stage 1 & Career stage 2 & Career stage 3 & Career stage 4 \\
\hline $\begin{array}{l}\text { Daily tasks / routines } \\
\text { are challenging, many } \\
\text { job demands are new } \\
\text { and unknown }\end{array}$ & $\begin{array}{l}\text { Conflict-laden soci } \\
\text { resolution are cons }\end{array}$ & $\begin{array}{l}\text { teractions and their } \\
\text { ed challenging }\end{array}$ & $\begin{array}{l}\text { Specific tasks } \\
\text { outside the routine } \\
\text { are challenging; } \\
\text { proactive search for } \\
\text { such challenges }\end{array}$ \\
\hline \multicolumn{2}{|c|}{$\begin{array}{c}\text { Feeling of continuous personal growth at } \\
\text { work }\end{array}$} & \multicolumn{2}{|c|}{$\begin{array}{c}\text { Personal growth at work felt after discrete } \\
\text { events }\end{array}$} \\
\hline $\begin{array}{l}\text { Focus on personal } \\
\text { and cognitive } \\
\text { development }\end{array}$ & \multicolumn{2}{|c|}{ Focus on social development } & $\begin{array}{l}\text { Focus on selected } \\
\text { topics of expertise; } \\
\text { personal growth in } \\
\text { private domain gains } \\
\text { importance }\end{array}$ \\
\hline
\end{tabular}

Fig. 1 Childcare providers' experience of personal growth: Similarities and differences depending on the career stage

At some point, it [personal growth] ends up in the fullness that you may have experienced in the past. Now they are phases that are more isolated. (Female childcare provider, 58 years old, 39 years of job experience, Career Stage 4)

It became apparent that childcare providers in the first two career stages experienced personal growth as continuous, because they viewed their daily work as full of challenges. That is, many daily tasks were still new and unknown for them, resulting in a feeling of constantly mastering challenging demands at work:

I am growing in every little situation at work. Because of the nature of the work-everything is new-you have to reflect very often and deal intensively with many different topics... It's a perpetual process that does not stop; you cannot say "I have reached point X". (Female childcare provider, 22 years old, 0.4 years of job experience, Career Stage 1)

There is no such thing as a finished, all-knowing person, so it goes on and on. It's a constant learning process. (Female childcare provider, 29 years old, 10 years of job experience, Career Stage 2)

In contrast, their colleagues in the last two career stages tended to describe personal growth based on discrete events.

So, I think there are times when you grow and there are times when you don't. If you are a beginner, it is very intense. But now it depends on what you are confronted with ... you maybe have to deal with a difficult topic ... and then 
there are other days that flow quite calmly along. (Female childcare provider, 53 years old, 35 years of job experience, Career Stage 4)

As a beginner, I had the impression that I was growing exponentially ... which has now become less so ... now there are only selected moments in which you grow ... I also note that it may be more valuable to actively and selectively pick out topics that you personally work on. (Male childcare provider, 37 years old, 12 years of job experience, Career Stage 3)

In Career Stages 2 and 3, the description of challenging demands that stimulate personal growth became more specific. Interviewees often reported conflict-laden social interactions and their resolutions as challenging. That is, they spoke of critical discussions with parents, disputes with colleagues and supervisors, or leading difficult trainees.

I am the tutor of my trainee, so I have to deal with what is not going so well. It's not easy for me. It's a conflict with this person you want to solve. (Female childcare provider, 29 years old, 10 years of job experience, Career Stage 2)

And then finally I told her [supervisor] that I did not like that. I had to struggle very hard to address that. I am not a person who likes to argue, but I had to address that to move forward. (Female childcare provider, 37 years old, 18 years of job experience, Career Stage 3)

Finally, in the last career stage, interviewees reported that challenging demands occurred outside of their daily job tasks. For example, they might take the form of a public speech on an educational topic or participating in a pedagogical committee. Interestingly, these challenges were often self-initiated and not imposed by others. That is, in the later stages of their careers, childcare providers seemed to be more proactive in finding new challenges.

And I stood up there and saw all the people and thought: "I just can't do this!" ... and then I started to talk. At some point, I realized that everyone was listening carefully ... I also ran for the works council and was elected, that's another aspect, where you deal again with new topics, that's nice, and you don't get rusty. (Female childcare provider, 53 years old, 35 years of job experience, Career Stage 4)

\subsection{Dimensions of development}

While respondents in Career Stage 1 emphasized the realm of personal and cognitive development (i.e., development of attitudes, values, skills, and abilities they can also use in other life domains), interviewees in Career Stages 2 and 3 addressed topics in the social sphere (i.e., development through differentiation from others; social conflicts viewed as learning opportunities). In the final career stage, interviewees described growth following selected, discrete events and emphasized that the domain of private life gains importance in terms of opportunities for growth: 
Personal growth means that someone evolves in work that strengthens the personality. (Female childcare provider, 36 years old, 12 years of job experience, Career Stage 1)

I have to develop clear points of view and patience, because the children always test how far they can go. I can really use everything I learn here in my life. (Female childcare provider, 30 years old, 0.1 years of job experience, Career Stage 1)

I think that's one of the sticking points, team development and conflict management ... They are tackled quite differently in one's younger years than now with some work experience. (Female childcare provider, 26 years old, 5.5 years of job experience, Career Stage 2)

At this moment in my life, there is more personal growth in the private sphere. It is not so much about work-related topics. For example, I have to take care of my parents at home. Of course, you can always learn something in your job. But the private life now gains importance. (Female childcare provider, 53 years old, 35 years of job experience, Career Stage 4)

I am having fun with the kids at work ... in the past, I was under the pressure of expectations, I felt that I had to perform. Now I enjoy it ... I like to go to work ... I still have free time where I can also grow. (Female childcare provider, 59 years old, 40 years of job experience, Career Stage 4)

\section{Discussion}

The aim of our study was to explore personal growth at work from a career perspective. In grounded theory-based interviews with 29 childcare providers, we found some similarities in how respondents from different career stages construed personal growth at work; however, there were also differences depending on career stage. Childcare providers' notions of personal growth at work were united by the fact that they involved both positive affect and an upward developmental trajectory in response to mastering challenging demands at work. That is, in line with existing conceptualizations of personal growth (Dutton et al. 2011; Spreitzer et al. 2005), the interviewees mentioned both hedonic and eudaimonic aspects when reflecting on personal growth. Growth comprises pleasant feelings-however, challenges must be mastered before they arise. Thus, it seems that personal growth at work is only possible when challenges are tackled, that is, when workers leave their comfort zone.

Apart from these similarities, however, there were also three notable differences in the interviewees' views of personal growth at work. First, the respondents differed in how they defined a challenge depending on career stage. For beginners in the exploration phase of their careers, daily tasks and routines were themselves already challenging. Professionals in the middle of their careers, in the establishment and maintenance stages, focused more on social conflicts and their resolutions, while interviewees at the end of their careers were more likely to consider self-selected, nonroutine tasks as challenges. Secondly, the respondents differed in how continuous they considered growth to be. In the first half of their careers, childcare providers 
experienced personal growth as an ongoing, continuous process, whereas in the second half of their careers, childcare providers tended to describe personal growth as resulting from discrete events. Finally, the respondents also differed in the sphere of development they considered most important. Beginners in the exploration phase emphasized their personal and cognitive development (e.g., development of skills, abilities, and values), while professionals in the middle of their careers pointed to developments in the social sphere (e.g., social conflicts regarded as learning opportunities). In the last career stage, respondents described growth following selected events and noted that the private domain gains weight in terms of opportunities for growth.

In summary, this research contributes to the literature on personal growth by integrating personal growth and career research (Super 1957, 1980). On the one hand, this new perspective demonstrates a common understanding of personal growth among professionals in terms of involving hedonic and eudaimonic aspects (Dutton et al. 2011; Spreitzer et al., 2005). On the other hand, this perspective points out several differences in professionals' views of personal growth depending on career stage. Interestingly, some of these differences resonate with existing aging research and theories (e.g., Baltes 1997; Carstensen 2006; Taneva et al. 2016). In line with Taneva et al. (2016), our data also show that development and growth still occurs in the late stages of professional careers. It even seems that older workers are more proactive in seeking out opportunities for growth (sometimes outside the work domain). In line with socio-emotional selectivity theory (SST, Carstensen 2006; Carstensen et al. 1999), which proposes motivational shifts from knowledge gain to emotional well-being when (life)time is running out, our interviews show that childcare providers in the exploration phase of their careers emphasize their development in terms of learning new skills and abilities. In contrast, several childcare providers at the end of their careers reported having more fun with the children, free of pressure from parents or supervisors. That is, in line with SST, workers at the end of their careers seem to focus more on emotional well-being and savoring the present. It further seems that childcare is a work context in which it is possible to compensate for the age-related loss of certain skills (e.g., speed of action and information processing) through experience and knowledge (i.e., crystallized cognitive pragmatics; Baltes 1997). That is, childcare providers at the end of their careers seemed to be experts to whom others turned to for advice (e.g., they gave speeches on topics of expertise).

\subsection{Limitations and future research}

Our study is exploratory in nature, that is, it is based on a relatively small sample-from an occupational group in which significantly more women than men work. Although we reached theoretical saturation (Glaser and Strauss 1967) after 29 interviews, it would be desirable to corroborate our findings in a larger, longitudinal study and in different work contexts.

It would also be interesting for future research to include modern career research frameworks (e.g., the idea of protean careers; Hall 2004). Moreover, quantitative longitudinal research on personal growth should consider that the frequency, in- 
tensity, and continuity of personal growth differs across the lifespan. In addition, other individual factors (e.g., personality) and contextual factors (e.g., industry) should be included in future research to gain deeper insight into antecedents of personal growth across the career- and lifespan. With respect to the topic of mastering challenges, it could be interesting to examine specific emotions more closely, such as pride (Williams and DeSteno 2009). Moreover, it could be worthwhile to ask whether respondents distinguish between personal growth and personality development at work. Some researchers have suggested that personal growth is intended and personality development is unintended and just happens (Bauer and McAdams 2004) - however, in our study, we gained the impression that the interviewees did not differentiate between these two forms of development.

\subsection{Practical recommendations}

Although our findings stem from an exploratory study, we have also attempted to formulate some practical recommendations on how to support employees' personal growth at different career stages (see Fig. 2 for an overview). To facilitate personal growth on a general level, practitioners should help to establish an organizational climate of learning and development (Elliott and Dweck 1988). That is, they should encourage the mindset that challenges are something positive to embrace and seek out. If challenges are considered an opportunity to learn and grow rather than a potential source of failure and stress, workers might leave their comfort zones more frequently, look upon conflicts more positively, and seek out challenging tasks themselves.

\section{How to facilitate personal growth at work}

Establish an organizational climate of learning - encourage the mindset that challenges are an opportunity to learn and grow and not a source of failure

\begin{tabular}{|c|c|c|}
\hline Career stage 1 & Career stage 2 & Career stage 4 \\
\hline $\begin{array}{l}\text { Be careful not to ask } \\
\text { too much of } \\
\text { beginners - keep in } \\
\text { mind that everyday } \\
\text { tasks are challenging } \\
\text { for them. } \\
\text { Develop careful } \\
\text { onboarding and } \\
\text { mentoring schemes to } \\
\text { support early career } \\
\text { workers. }\end{array}$ & $\begin{array}{l}\text { Support workers in the midst of their } \\
\text { career with further training in team } \\
\text { building, conflict management, } \\
\text { cooperation, and leadership. } \\
\text { Make sure to invest in the development } \\
\text { of positive workplace relationships; } \\
\text { foster and encourage civility, citizenship } \\
\text { behavior, and collegiality to support the } \\
\text { resolution of (inevitable) conflicts. }\end{array}$ & $\begin{array}{l}\text { Give as much } \\
\text { autonomy as possible } \\
\text { to enable workers in } \\
\text { the late stages of their } \\
\text { career to find } \\
\text { challenging tasks on } \\
\text { their own. Also } \\
\text { stimulate growth by } \\
\text { offering new tasks } \\
\text { and roles. } \\
\text { Appreciate workers' } \\
\text { balance and expertise. }\end{array}$ \\
\hline
\end{tabular}

Fig. 2 Practical recommendations: Encouraging personal growth at different career stages 
Managers should also differentiate their support depending on employees' career stage: They should develop careful onboarding and mentoring schemes for earlycareer workers, keeping in mind that daily routines are already challenging for them. To support workers in the middle of their careers, managers should provide further training on social development topics (e.g., conflict management, leadership, and team building). They should also place value on fostering positive workplace relationships. That is, they should ensure an environment characterized by civility and collegiality (Leiter et al. 2011). Finally, managers should give as much leeway and autonomy as possible to professionals in the later stages of their careers so that they can find and select tasks and challenges that will allow them to grow. Nevertheless, supervisors can also promote personal growth in later career stages by providing a stimulating work environment, for example, offering new roles, ideas, and perspectives on late-career workers' tasks and responsibilities.

In conclusion, our study has shown that the experience of personal growth differs both quantitatively and qualitatively across workers' careers-with important implications not only for researchers but also for practitioners. We hope that this first, exploratory study stimulates more research in this field, making it possible to provide more detailed practical recommendations.

Acknowledgements We thank Leona Holzbecher for her help with the double coding of the data.

Funding Open Access funding provided by Projekt DEAL.

Open Access This article is licensed under a Creative Commons Attribution 4.0 International License, which permits use, sharing, adaptation, distribution and reproduction in any medium or format, as long as you give appropriate credit to the original author(s) and the source, provide a link to the Creative Commons licence, and indicate if changes were made. The images or other third party material in this article are included in the article's Creative Commons licence, unless indicated otherwise in a credit line to the material. If material is not included in the article's Creative Commons licence and your intended use is not permitted by statutory regulation or exceeds the permitted use, you will need to obtain permission directly from the copyright holder. To view a copy of this licence, visit http://creativecommons.org/licenses/by/4. $0 /$.

\section{References}

Aristotle (2001). Nicomachean ethics. In R. McKeon (Ed.), The basic works of Aristotle (pp. 928-1112). New York: Modern Library. Original work published 350 B.C.E., Oxford translation 1912-1954.

Bakeman, R., \& Gottman, J. M. (1986). Observing interaction: an introduction to sequential analysis. New York: Cambridge University Press.

Baltes, P. B. (1997). On the incomplete architecture of human ontogeny: selection, optimization, and compensation as foundation of developmental theory. American Psychologist, 52, 366-380. https://doi. org/10.1037/0003-066X.52.4.366.

Bauer, J. J., \& McAdams, D.P. (2004). Personal growth in adults' stories of life transitions. Journal of Personality, 72, 573-602. https://doi.org/10.1111/j.0022-3506.2004.00273.x.

Bennett, N., \& Lemoine, G. J. (2014). What a difference a word makes: Understanding threats to performance in a VUCA world. Business Horizons, 57, 311-317. https://doi.org/10.1016/j.bushor.2014.01. 001.

Cappelli, P. (1999). The new deal at work: managing the market-driven workforce. Boston: Harvard Business School Press.

Carmeli, A., \& Spreitzer, G. M. (2009). Trust, connectivity, and thriving: implications for innovative behaviors at work. The Journal of Creative Behavior, 43, 169-191. https://doi.org/10.1002/j.2162-6057. 2009.tb01313.x. 
Carmeli, A., Ben-Hador, B., Waldman, D. A., \& Rupp, D.E. (2009). How leaders cultivate social capital and nurture employee vigor: implications for job performance. Journal of Applied Psychology, 94, 1553-1561. https://doi.org/10.1037/a0016429.

Carstensen, L.L. (2006). The influence of a sense of time on human development. Science, 312, 1913-1915. https://doi.org/10.1126/science.1127488.

Carstensen, L.L., Isaacowitz, D. M., \& Charles, S. T. (1999). Taking time seriously: a theory of socioemotional selectivity. American Psychologist, 54, 165-181. https://doi.org/10.1037/0003-066X.54.3. 165 .

Caza, B.B., \& Milton, L.P. (2012). Resilience at work: Building capability in the face of adversity. In G.M. Spreitzer \& K.S. Cameron (Eds.), The Oxford handbook of positive organizational scholarship (pp. 895-908). New York: Oxford University Press. https://doi.org/10.1093/oxfordhb/ 9780199734610.013 .0068 .

Corbin, J., \& Strauss, A. (2015). Basics of qualitative research. Thousand Oaks: SAGE.

Diener, E., Lucas, R. E., Schimmack, U., \& Helliwell, J. F. (2009). Well-being for public policy. New York: Oxford University Press.

Dutton, J.E., Roberts, L. M., \& Bednar, J. (2011). Prosocial practices, positive identity, and flourishing at work. In S. I. Donaldson, M. Csikszentmihalyi \& J. Nakamura (Eds.), Applied positive psychology: Improving everyday life, health, schools, work, and society (pp. 155-170). New York: Routledge/ Taylor \& Francis Group.

Elliott, E.S., \& Dweck, C.S. (1988). Goals: An approach to motivation and achievement. Journal of Personality and Social Psychology, 54, 5-12. https://doi.org/10.1037/0022-3514.54.1.5.

Glaser, B. G., \& Strauss, A. L. (1967). The discovery of grounded theory: strategies for qualitative research. New York: Aldine.

Hackman, J.R., \& Oldham, G.R. (1976). Motivation through the design of work: test of a theory. Organizational Behavior and Human Performance, 16, 250-279. https://doi.org/10.1016/00305073(76)90016-7.

Hackman, J. R., \& Oldham, G. R. (1980). Work redesign. Reading: Addison-Wesley.

Hall, D. T. (2004). The protean career: a quarter-century journey. Journal of Vocational Behavior, 65, 1-13. https://doi.org/10.1016/j.jvb.2003.10.006.

Hertel, G., \& Zacher, H. (2015). Managing the aging workforce. In D. S. Ones, N. Anderson, C. Viswesvaran \& H. K. Sinangil (Eds.), The SAGE handbook of industrial, work, \& organizational psychology 2nd edn. Vol. 3. New York: SAGE.

Huta, V. (2015). An overview of hedonic and eudaimonic well-being concepts. In L. Reinecke \& M. B. Oliver (Eds.), Handbook of media use and well-being (chapter 2). New York: Routledge.

Keyes, C.L.M. (2002). The mental health continuum: from languishing to flourishing in life. Journal of Health and Social Behavior, 43, 207-222. https://doi.org/10.2307/3090197.

Kleine, A.-K., Rudolph, C. W., \& Zacher, H. (2019). Thriving at work: a meta-analysis. Journal of Organizational Behavior. https://doi.org/10.1002/job.2375.

Lamb, D., \& Cogan, N. (2016). Coping with work-related stressors and building resilience in mental health workers: a comparative focus group study using interpretative phenomenological analysis. Journal of Occupational and Organizational Psychology, 89, 474-492. https://doi.org/10.1111/joop.12136.

Leiter, M.P., Laschinger, H. K.S., Day, A., \& Oore, D.G. (2011). The impact of civility interventions on employee social behavior, distress, and attitudes. Journal of Applied Psychology, 96, 1258-1274. https://doi.org/10.1037/a0024442.

McDonnell, A. (2011). Still fighting the "war for talent"? Bridging the science versus practice gap. Journal of Business and Psychology, 26, 169-173. https://doi.org/10.1007/s10869-011-9220-y.

Mey, G., \& Mruck, K. (2010). Handbuch qualitative Forschung in der Psychologie. Wiesbaden: VS.

Nagy, N., Froidevaux, A., \& Hirschi, A. (2019). Lifespan perspectives on careers and career development. In B. B. Baltes, C. W. Rudolph \& H. Zacher (Eds.), Work across the lifespan (pp. 235-259). London: Academic Press. https://doi.org/10.1016/B978-0-12-812756-8.00010-4.

Niessen, C., Mäder, I., Stride, C., \& Jimmieson, N.L. (2017). Thriving when exhausted: the role of perceived transformational leadership. Journal of Vocational Behavior, 103, 41-51. https://doi.org/10. 1016/j.jvb.2017.07.012.

Niessen, C., Sonnentag, S., \& Sach, F. (2012). Thriving at work-a diary study. Journal of Organizational Behavior, 33, 468-487. https://doi.org/10.1002/job.763.

Paterson, T. A., Luthans, F., \& Jeung, W. (2014). Thriving at work: impact of psychological capital and supervisor support. Journal of Organizational Behavior, 35, 434-446. https://doi.org/10.1002/job. 1907. 
Paton, D. (2014). Posttraumatic growth in disaster and emergency work. In I. L. G. Calhoun \& R. G. Tedeschi (Eds.), Handbook of posttraumatic growth: Research and practice (pp. 225-247). New York: Psychology Press.

Peterson, C., \& Seligman, M.E.P. (2004). Character strengths and virtues: a handbook and classification. New York: Oxford University Press.

Prem, R., Ohly, S., Kubicek, B., \& Korunka, C. (2017). Thriving on challenge stressors? Exploring time pressure and learning demands as antecedents of thriving at work. Journal of Organizational Behavior, 38, 108-123. https://doi.org/10.1002/job.2115.

Ryan, R. M., \& Frederick, C. (1997). On energy, personality, and health: Subjective vitality as a dynamic reflection of well-being. Journal of Personality, 65, 529-565. https://doi.org/10.1111/j.1467-6494. 1997.tb00326.x.

Ryff, C. D. (1995). Psychological well-being in adult life. Current Directions in Psychological Science, 4 , 99-104. https://doi.org/10.1111/1467-8721.ep10772395.

Ryff, C.D., \& Singer, B.H. (2008). Know thyself and become what you are: a eudaimonic approach to psychological well-being. Journal of Happiness Studies, 9, 13-39. https://doi.org/10.1007/s10902006-9019-0.

Shirom, A. (2003). Feeling vigorous at work? The construct of vigor and the study of positive affect in organizations. In P. M. Perrewé \& D. Ganster (Eds.), Emotional and physiological processes and positive intervention strategies (Research in occupational stress and well Being (Vol. 3, pp. 135-164). Bingley: Emerald Group Publishing Limited.

Shirom, A., Toker, S., Berliner, S., Shapira, I., \& Melamed, S. (2008). The effects of physical fitness and feeling vigorous on self-rated health. Health Psychology, 27, 567-575. https://doi.org/10.1037/02786133.27.5.567.

Spreitzer, G., Porath, C.L., \& Gibson, C.B. (2012). Toward human sustainability: How to enable more thriving at work. Organizational Dynamics, 41, 155-162. https://doi.org/10.1016/j.orgdyn.2012.01. 009.

Spreitzer, G., Sutcliffe, K., Dutton, J., Sonenshein, S., \& Grant, A. M. (2005). A socially embedded model of thriving at work. Organization Science, 16, 537-549. https://doi.org/10.1287/orsc.1050.0153.

Super, D. E. (1957). The psychology of careers; an introduction to vocational development. Oxford: Harper \& Bros.

Super, D.E. (1980). A life-span, life-space approach to career development. Journal of Vocational Behavior, 16, 282-298. https://doi.org/10.1016/0001-8791(80)90056-1.

Taneva, S. K., Arnold, J., \& Nicolson, R. (2016). The experience of being an older worker in an organization: a qualitative analysis. Work, Aging and Retirement, 2, 396-414. https://doi.org/10.1093/workar/ waw011.

Tedeschi, R.G., \& Calhoun, L.G. (2004). Posttraumatic growth: conceptual foundations and empirical evidence. Psychological Inquiry, 15, 1-18. https://doi.org/10.1207/s15327965pli1501_01.

Williams, L.A., \& DeSteno, D. (2009). Pride: Adaptive social emotion or seventh sin? Psychological Science, 20, 284-288. https://doi.org/10.1111/j.1467-9280.2009.02292.x. 


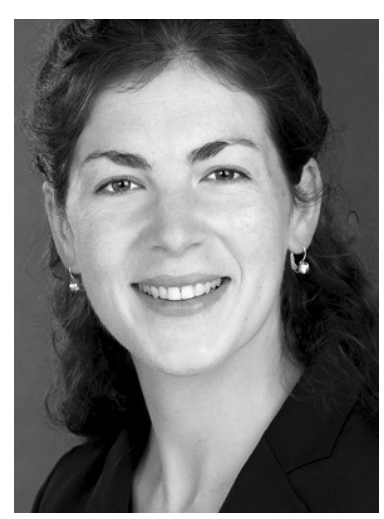

Dr. Sabine Hommelhoff Dipl.-Psych., assistant professor in Work and Organizational Psychology at Friedrich-Alexander-University Erlangen-Nürnberg. Her research focuses on workplace relationships, which comprises both social relationships people have at work as well as relationships people have to their work.

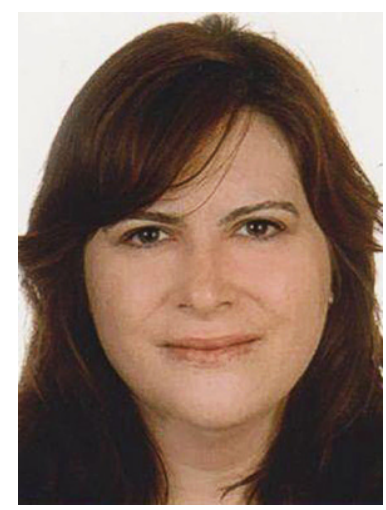

Carina Schröder is both a psychologist by training and a professional childcare worker with more than six years of work experience in childcare. She worked for two years as a research associate at the Chair of Work and Organizational Psychology at Friedrich-Alexander-University Erlangen-Nürnberg.

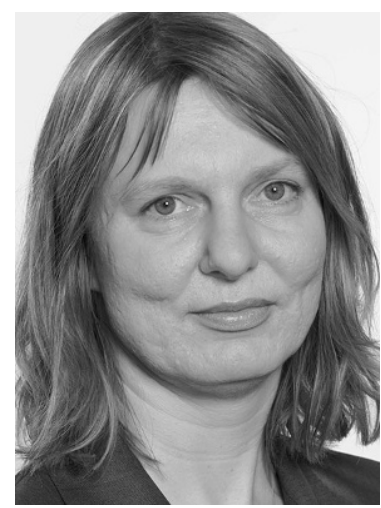

Prof. Dr. Cornelia Niessen Dipl.-Psych., professor and chair of Work and Organizational Psychology at Friedrich-Alexander-University Erlangen-Nürnberg. Her research focuses on health and performance. In particular, she is interested in processes that foster the ability of employees to deal with change in an effective and healthy manner. In this context, she has published several articles on thriving at work. 